\title{
SEGURANÇA ALIMENTAR VS. GLOBALIZAÇÃO ECONÔMICA: POSSÍVEIS AMEAÇAS À SUSTENTABILIDADE AMBIENTAL, À BIODIVERSIDADE E AOS DIREITOS HUMANOS AGROALIMENTARES
}

\author{
FOOD SECURITY VS. ECONOMIC GLOBALIZATION: \\ POTENTIAL THREATS TO ENVIRONMENTAL SUSTAINABILITY, BIODIVERSITY \\ AND AGRIFOOD HUMAN RIGHTS
}

\author{
SEGURIDAD ALIMENTARIA VS. GLOBALIZACIÓN ECONÓMICA: \\ POSIBLES AMENAZAS A LA SUSTENTABILIDAD AMBIENTAL, A LA \\ BIODIVERSIDAD Y A LOS DERECHOS HUMANOS AGROALIMENTARIOS
}

\begin{abstract}
ELISABETE MANIGLIA https:// orcid.org/0000-0002-4484-6927 / http://lattes.cnpq.br/3994325904492685 / manigliaelisabete@gmail.com Universidade Estadual Paulista "Julio de Mesquita Filho" - UNESP

Franca, SP, Brasil.
\end{abstract} https://orcid.org/0000-0002-4993-7596 / http://lattes.cnpq.br/2102767617751404 / gilrcneto@yahoo.com.br Universidade Estadual Paulista "Julio de Mesquita Filho" - UNESP

Franca, SP, Brasil.

\section{RESUMO}

0 artigo analisa a segurança alimentar e os direitos humanos a ela relacionados sob a ótica da globalização econômica, tendo por base o atual modelo de produção agrícola e como o mesmo afeta a sustentabilidade ambiental, a biodiversidade e os direitos humanos agroalimentares. O objetivo deste trabalho é o de verificar se é possível que a atual agricultura, inserida no contexto da globalização econômica, permite a existência de uma verdadeira segurança alimentar, que zele pela sustentabilidade ambiental, pela proteção da biodiversidade e que seja capaz de respeitar e atender aos direitos humanos relacionados ao âmbito agroalimentar. A análise metodológica escolhida é o método indutivo. Conclui-se que o modelo atual predominante de produção agrícola, institucionalizado para atender aos interesses de alguns em detrimento da maioria da sociedade, não é a melhor opção para a busca da segurança alimentar, a sustentabilidade ambiental, a proteção à biodiversidade e o respeito aos direitos humanos agroalimentares.

Palavras-chave: biodiversidade; direitos humanos; modelo de produção agrícola; segurança alimentar; sustentabilidade ambiental.

\footnotetext{
ABSTRACT

This paper analyzes the food security and the related human rights in times of economic globalization, based on the current model of agricultural production and how it affects environmental sustainability, biodiversity and agrifood human rights. The objective of this paper is to verify whether is possible that the current agriculture, into the context of economic globalization, allows the existence of a real food safety, which promotes the environmental sustainability, the protection of biodiversity and to be able to respect and comply the human rights related to agrifood scope. The chosen methodological analysis is the inductive method. It is conclude that the predominant current model of agricultural production, institutionalized to attend to interests of some to the detriment of the
} 
SEGURANÇA ALIMENTAR VS. GLOBALIZAÇÃO ECONÔMICA: POSSÍVEIS AMEACAS À SUSTENTABILIDADE AMBIENTAL, À BIODIVERSIDADE E AOS DIREITOS HUMANOS AGROALIMENTARES

majority of society, is not the best option for the seek of food security, environmental sustainability, protection of biodiversity and respect for agrifood human rights.

Keywords: biodiversity; human rights; genetically agricultural production model; food security; environmental sustainability.

\section{RESUMEN}

El artículo analiza la seguridad alimentaria y los derechos humanos a ella relacionados bajo la óptica de la globalización económica, teniendo como base el actual modelo de producción agrícola y cómo afecta la sostenibilidad ambiental, la biodiversidad y los derechos humanos agroalimentarios. El objetivo de este trabajo es el de verificar si es posible que la actual agricultura, inserta en el contexto de la globalización económica, permita la existencia de una verdadera seguridad alimentaria, que vela por la sustentabilidad ambiental, por la protección de la biodiversidad y que sea capaz de respetar y atender a los derechos humanos relacionados con el alcance agroalimentario. El análisis metodológico elegido es el método inductivo. Se concluye que el modelo actual predominante de producción agrícola, institucionalizado para atender a los intereses de algunos en detrimento de la mayoría de la sociedad, no es la mejor opción para la búsqueda de la seguridad alimentaria, la sostenibilidad ambiental, la protección a la biodiversidad y el respeto a los derechos derechos humanos agroalimentarios.

Palabras clave: biodiversidad; derechos humanos; modelo de producción agrícola; seguridad alimentaria; sostenibilidad del medio ambiente.

\section{SUMÁRIO}

INTRODUÇÃO; 1 APONTAMENTOS SOBRE DIREITOS HUMANOS AGROALIMENTARES; 2 SEGURANÇA ALIMENTAR; 3 PANORAMA ATUAL DA AGRICULTURA E GLOBALIZAÇÃO ECONÔMICA; 4 SUSTENTABILIDADE AMBIENTAL E PROTEÇÃO À BIODIVERSIDADE; CONCLUSÃO; REFERÊNCIAS

\section{INTRODUÇÃO}

O exponencial aumento populacional no planeta desperta preocupação com a necessidade de produzir alimentos de forma a atender à demanda de toda a humanidade, sem prejuízo ao meio ambiente.

A evolução agrária ocorrida especialmente a partir da Revolução Verde gerou diversas modificações no cenário da agricultura, que veio a se tornar globalizada. As novas diretrizes agrícolas ditadas pelo modelo neoliberal permitiram a expansão das fronteiras agrícolas e o enriquecimento de alguns, em detrimento de uma grande maioria de trabalhadores do campo, a quem restaram diversos problemas econômicos e sociais a serem resolvidos. Os efeitos ambientais de tal opção político-econômica são péssimos, uma vez que os frutos tecnológicos da Revolução Verde ocasionam diversos males à natureza.

O direito humano à alimentação adequada é influenciado pelas questões supracitadas, já que a principal finalidade de existência da agropecuária é a de propiciar gêneros para a alimentação humana. A globalização econômica, com o controle dos principais aspectos do agronegócio por um pequeno grupo de empresas multinacionais, pode afetar a segurança 
alimentar da humanidade. Além disso, a própria biodiversidade poderá ser prejudicada pelos interesses econômicos das grandes empresas, afetando as conquistas jurídicas mais básicas do homem.

O objetivo deste trabalho é o de verificar se é possivel que a atual agricultura, inserida no contexto da globalização econômica, permita a existência de uma verdadeira segurança alimentar, que zele pela sustentabilidade ambiental, pela proteção da biodiversidade e que seja capaz de respeitar e atender aos direitos humanos relacionados à seara agroalimentar.

Sob o aspecto metodológico, fez-se opção pelo método indutivo no intuito de realizar diagnósticos particulares dos diferentes temas que permeiam o estudo, a fim de pontuar aspectos relevantes acerca do cenário analisado e permitir que o mesmo seja estudado na sua totalidade para fins de conclusão.

Inicialmente, apresentam-se apontamentos acerca de direitos humanos ligados à área agroalimentar, como o direito à alimentação adequada, o direito à vida, o direito à paz $\mathrm{e}$ também o direito humano ao meio ambiente, de forma a demonstrar de forma breve seu caminhar histórico e status atual. Em seguida, apresenta-se um importante conceito afeto ao direito à alimentação - que é o de segurança alimentar - também a partir de sua evolução histórica.

Posteriormente, trabalha-se com o atual panorama da agricultura inserida no cenário atual de globalização econômica. E, finalmente, trata-se dos aspectos de sustentabilidade ambiental na agricultura atual e em que medida isso afeta a proteção à biodiversidade, pois o modelo predominante de produção agrária poderá fazer com que a balança dos direitos humanos à alimentação e ao meio ambiente ecologicamente equilibrado se desregule.

\section{APONTAMENTOS SOBRE DIREITOS HUMANOS AGROALIMENTARES}

O regime internacional para a proteção dos direitos humanos surgiu a partir do reconhecimento das liberdades fundamentais ocorrido após a Segunda Guerra Mundial (19391945), especialmente com a positivação da Declaração Universal dos Direitos Humanos (1948).

A partir desse importante marco no Direito Internacional, os Estados tiveram que restringir seus poderes soberanos, com o reconhecimento quanto a tal situação quando da 
adoção do Pacto Internacional dos Direitos Econômicos, Sociais e Culturais e também do Pacto Internacional dos Direitos Civis e Políticos, ambos em 1966¹.

Quanto a alguns dos aspectos mais diretamente relacionáveis ao conceito de segurança alimentar, os principais direitos humanos que estão ligados a ela seriam: o direito à alimentação, de forma mais evidente, e também o direito ao meio ambiente, em decorrência do conceito legal da seguridade alimentar.

Com influência dos diplomas internacionais já mencionados acima, além da Declaração de Direitos Humanos de Viena (1993), percebe-se que o direito à alimentação está previsto em diversos instrumentos na ordem jurídica internacional. Quanto à internalização desse direito nos países latinos, Dirceu Pereira Siqueira explica que os tópicos previstos na normativa internacional sobre a temática acabam por se repetir na tradição constitucional iberoamericana $^{2}$. Ainda assim, a partir dos Pactos de 1966, passa a existir o reconhecimento do direito à alimentação como direito humano básico. Iniciou-se então a trajetória da busca pela garantia de alimentação a toda a humanidade.

De acordo com a Declaração Universal dos Direitos Humanos, a alimentação deve ser assegurada a todas as pessoas, de forma a lhes garantir principalmente a saúde, como parte do reconhecimento da dignidade da pessoa humana. Entende-se que, para isso, faz-se necessária a chamada alimentação adequada. A alimentação é um direito de cada cidadão e nenhum fator, de qualquer ordem que seja, justifica a negação do acesso à alimentação adequada a um ser humano ${ }^{3}$.

Segundo Vanesca Freitas Bispo, o direito à alimentação, aliado a outros, é considerado um instrumento que fornece ao homem um padrão de vida digno e de bem-estar. Isso a torna um item do rol de obrigações estatais e não mero auxílio social ${ }^{4}$.

Para ela, ainda:

[...] o conceito de alimentação pressupõe ações em um caráter muito mais amplo do que apenas o seu aspecto qualitativo ou quantitativo, ou seja, o seu aspecto nutricional. [...] requer políticas que tenham essencialmente um caráter estrutural, as quais objetivam o desenvolvimento gradativo e contínuo de todos

\footnotetext{
${ }^{1}$ BOSSELMANN, Klaus. O princípio da sustentabilidade: transformando direito e governança. Tradução de Phillip Gil França. São Paulo: Editora Revista dos Tribunais, 2015, p. 146.

2 SIQUEIRA, Dirceu Pereira. Teoria geral do direito à alimentação: cultura, cidadania e legitimação. Birigui: Boreal Editora, 2015, p. 49.

3 VALENTE, Flávio Luiz Schieck. Do combate à fome à segurança alimentar e nutricional: o direito à alimentação adequada. In: VALENTE, Flávio Luiz Schieck (Org.). Direito humano à alimentação: desafios e conquistas. São Paulo: Cortez, 2002, p. 37-70.

${ }^{4}$ BISPO, Vanesca Freitas. Direito fundamental à alimentação adequada: a efetividade do direito pelo mínimo existencial e a reserva do possível. Curitiba: Juruá, 2014 p. 71-72.
} 
SEGURANÇA ALIMENTAR VS. GLOBALIZAÇÃO ECONÔMICA: POSSÍVEIS AMEACAS À SUSTENTABILIDADE AMBIENTAL, À BIODIVERSIDADE E AOS DIREITOS HUMANOS AGROALIMENTARES

os fatores que direta ou indiretamente afetam esse direito. Isso implica no respeito a todas as dimensões previstas na lei de segurança alimentar e nutricional, bem como outras que possam ter relação com o direito humano fundamental à alimentação adequada ${ }^{5}$.

O direito à alimentação adequada é o direito mais básico do homem, vinculando-se diretamente ao próprio direito à vida - pois sem alimento não há como se ter vida. Para que essa vida seja uma vida digna, respeitando o princípio da dignidade da pessoa humana, o alimento deve ser acessível, seguro e em quantidade necessária para atender aos fins a que ele se destina.

A falta de alimentos em quantidades adequadas leva à insatisfação das sociedades, o que pode violar mais um direito humano: o direito à paz. A fome pode levar à guerra e uma guerra pode trazer a fome. Esse seria um mal visível e retumbante da inadequação da alimentação.

Além disso, garantir a alimentação adequada passa por, necessariamente, preservar a natureza e as demais formas de vida para que a própria humanidade não seja prejudicada em algum dos seus direitos mais básicos. 0 direito humano ao meio ambiente vincula-se a esse propósito, sendo que a preocupação do homem com os aspectos ambientais do planeta data de um período próximo ao de sua preocupação jurídica alimentar.

O direito humano ao meio ambiente tem seu embasamento nos Pactos de 1966, já mencionados. Mas a proteção do meio ambiente se desenvolveu de modo diferente: surge com o reconhecimento de uma crise ambiental global. A positivação de normas de proteção ao meio ambiente se inicia com o Princípio I da Declaração de Estocolmo de 1972:

O homem tem o direito fundamental à liberdade, à igualdade e ao desfrute de condições de vida adequadas em um meio ambiente de qualidade tal que the permita levar uma vida digna e gozar de bem-estar, tendo a solene obrigação de proteger e melhorar o meio ambiente para as gerações presentes e futuras ${ }^{6}$.

A proteção ambiental é uma necessidade básica do homem, reconhecendo-se que o meio ambiente é indispensável. Embora legalmente os seres humanos valham muito mais do que o meio ambiente como objeto de proteção, o bem-estar do homem depende do bem-estar de todo os seres vivos.

\footnotetext{
${ }^{5}$ BISPO, Vanesca Freitas. Direito fundamental à alimentação adequada: a efetividade do direito pelo mínimo existencial e a reserva do possível. Curitiba: Juruá, 2014 p. 72.

${ }^{6}$ BRASIL. Ministério do Meio Ambiente. Declaração da Conferência das Nações Unidas para o Meio Ambiente Humano. Disponível em: http://www.mma.gov.br/estruturas/agenda21/_arquivos/estocolmo.doc. Acesso em 27 ago. 2016.
} 
A partir da Conferência de Estocolmo de 1972, as iniciativas para a proteção do direito ao meio ambiente aumentaram, se diversificaram e foram positivadas em diversas partes do planeta. O Brasil, claramente, sofreu influência do cenário internacional: a promulgação da Lei de Política Nacional do Meio Ambiente (Lei $n^{\circ}$ 6.938/1981) e a inserção de um capítulo específico sobre meio ambiente - de forma inédita - em uma Constituição brasileira, como aconteceu com a Carta Magna de 1988, evidenciam que a tutela ambiental passou a se estruturar sobre alicerces mais sólidos a partir dos anos 1980.

O estabelecimento da Política Nacional de Meio Ambiente (PNMA), após a criação da Secretaria Especial de Meio Ambiente (SEMA) - importante marco político-institucional quanto à mudança de mentalidade estatal no tocante ao tema - veio de maneira ampla e profunda. A tutela ambiental no Brasil passa a se desvincular da mera necessidade de desenvolvimento econômico especialmente a partir da promulgação de tal política - já que, antes, não havia uma política ambiental propriamente dita. As políticas esparsas vigentes anteriormente fomentavam a exploração dos recursos naturais, o desbravamento do território, tratavam de temas voltados ao saneamento e aos interesses econômicos em geral ${ }^{7}$.

A PNMA, assim, surgiu como medida estatal para a busca da "preservação, melhoria e recuperação da qualidade ambiental propícia à vida, visando assegurar, no País, condições ao desenvolvimento sócio-econômico [sic], aos interesses da segurança nacional e à proteção da dignidade da vida humana", conforme o caput de seu artigo $2^{\circ 8}$.

Alguns anos depois, o direito humano ao meio ambiente se consolida em sede constitucional no Brasil. Embora a Emenda Constitucional $n^{\circ}$ 01/1969 tenha demonstrado uma preocupação do legislador com os aspectos ecológicos no aproveitamento agrícola de terras sujeitas a desastres naturais, é na Constituição Federal de 1988 que a expressão "meio ambiente" veio a ser usada pela primeira vez em norma dessa magnitude?

O legislador constituinte de 1988, portanto, elevou a proteção ao meio ambiente, consagrando-a como um dos cernes do ordenamento jurídico pátrio na atualidade. Mesmo que de forma textual relativamente enxuta, a Lei Maior positiva de forma adequada o zelo da sociedade

\footnotetext{
${ }^{7}$ ARRIAGA, Rodrigo Neves. A política ambiental brasileira e gaúcha: evolução, aspectos legais e seus instrumentos. 2011. 55f. Monografia (Especialização em Economia e Meio Ambiente). Setor de Ciências Agrárias, Universidade Federal do Paraná, Curitiba, 2011, p. 12.

${ }^{8}$ BRASIL. Lei $n^{\circ}$ 6.938, de 31 de agosto de 1981. Dispõe sobre a Política Nacional do Meio Ambiente, seus fins e mecanismos de formulação e aplicação, e dá outras providências. Diário Oficial da República Federativa do Brasil, Brasília, DF, 02 set. 1981. Disponível em: http://www.planalto.gov.br/ccivil_03/leis/L6938.htm. Acesso em 09 mar. 2019.

${ }^{9}$ MACHADO, Paulo Affonso Leme. Direito Ambiental Brasileiro. 19. ed., rev., atual. e ampl. São Paulo: Malheiros Editores, 2011, p. 132.
} 
brasileira por seus recursos ambientais através do caput do artigo 225, que afirma: "Todos têm direito ao meio ambiente ecologicamente equilibrado, bem de uso comum do povo e essencial à sadia qualidade de vida, impondo-se ao Poder Público e à coletividade o dever de defendê-lo e preservá-lo para as presentes e futuras gerações” ${ }^{10}$.

Alguns anos depois da consolidação da proteção constitucional ambiental no direito brasileiro, houve também a elevação de patamar jurídico da alimentação ao status de direito social constitucionalmente protegido, após um período prolongado de lutas sociais contra a fome e em prol da segurança alimentar no Brasil. Dessa maneira, por meio da Emenda Constitucional $n^{\circ} 64 / 2010$, inseriu-se a alimentação entre os direitos sociais constitucionais, no caput do artigo $6^{\circ}$ da Carta Magna brasileira ${ }^{11}$.

Vale lembrar que, para se alimentar, o homem/ser humano depende de outras formas de vida. Assim, o direito humano à alimentação e o direito humano ao meio ambiente devem ser reconhecidos e respeitados em conjunto para que se possa vir a atingir a verdadeira segurança alimentar.

\section{SEGURANÇA ALIMENTAR}

O conceito de segurança alimentar, cujas raízes históricas são concomitantes ao direito à alimentação, foi construído durante o transcorrer do século XX. Inicialmente, estava ligado à assistência alimentar, com uso de excedentes de alimentos. Assim sendo, a ideia era fortemente limitada ao âmbito de política estratégica quanto à estocagem dos mesmos.

Após a Segunda Guerra Mundial, que teve como algumas de suas heranças o aumento no comércio internacional de alimentos e na utilização de substâncias químicas para sua produção, promoveu-se uma reunião conjunta entre a Organização para a Alimentação e Agricultura (FAO) e a Organização Mundial da Saúde (OMS), ambas afetas à ONU, em 1950². A segurança alimentar agregou então um enfoque sanitário.

10 BRASIL. Constituição Federal. Brasília: Senado Federal, 1988. Disponível em: http://www.planalto.gov.br/ccivil_03/Constituicao/Constituicao.htm. Acesso em: 09 mar. 2019.

${ }^{11}$ BRASIL. Constituição (1988). Emenda Constitucional no 64, de 04 de fevereiro de 2010. Diário Oficial da República Federativa do Brasil, Brasília, DF, 04 fev. 2010. Disponível em: http://www.planalto.gov.br/ccivil_03/Constituicao/Emendas/Emc/emc64.htm\#art1. Acesso em: 09 mar. 2019.

12 ESTORNINHO, Maria João. Segurança alimentar e protecção do consumidor de organismos geneticamente modificados. Coimbra: Edições Almedina, 2008, p. 35. 
Após um período de escassez nos anos 1970, passou-se a entender a segurança alimentar como sendo uma questão ligada à produção de alimentos e não do direito a eles - uma visão produtivista e neomalthusiana ${ }^{13}$. Nessa mesma década, o conceito avançou de forma a refinar seu próprio arcabouço: eventos como a Conferência Mundial sobre a Alimentação (sediado em Roma, no ano de 1974) e a Conferência Mundial sobre Reforma Agrária e Desenvolvimento Rural (também na cidade de Roma, em 1979), na sua alçada de discussão, elevaram a compreensão do tema a patamares mais significativos.

A base da discussão nas Conferências dos anos 1970 foi o problema da fome, mas as questões históricas sobre o tema não foram esquecidas: reconheceu-se que a privação alimentar estava relacionada - de forma mais marcante nos países subdesenvolvidos - com o domínio colonial opressor que impedia o avanço socioeconômico e político de tais localidades. Em relação aos aspectos produtivos e econômicos da agricultura - ponto fundamental da discussão Elisabete Maniglia menciona que:

O enfoque estava no alimento e não no ser humano. Com o aumento na produção de alimentos, nos fins da década de 1970, o mundo despertou para a realidade e passou a encarar a situação da fome e desnutrição como um problema realmente de acesso e não de produção ${ }^{14}$.

Assim, a década de 1980 assiste à constatação de que a fome e a desnutrição eram causadas mais por problemas ligados ao acesso aos alimentos do que à produção dos mesmos. No período, ainda, o conceito passou a incluir questões como a oferta estável de alimentos e de garantia de acesso a eles, bem como de sua qualidade. De qualquer forma, o combate à miséria se fazia necessário para que se garantisse a segurança alimentar. Nesse sentido, Elisabete Maniglia afirma que:

O Banco Mundial, em 1986, definiu segurança alimentar como "o acesso por parte de todos, todo o tempo, a quantidades suficientes de alimentos para levar uma vida ativa e saudável”. Nesse ínterim, passa-se a visão de que alimentos na mesa significam poder aquisitivo e não autossuficiência na produção. Poder aquisitivo representa crescimento econômico, distribuição de renda e redução da pobreza ${ }^{15}$.

\footnotetext{
${ }^{13}$ VALENTE, Flávio Luiz Schieck. Do combate à fome à segurança alimentar e nutricional: o direito à alimentação adequada. In: VALENTE, Flávio Luiz Schieck (Org.). Direito humano à alimentação: desafios e conquistas. São Paulo: Cortez, 2002, p. 37-70.

${ }^{14}$ MANIGLIA, Elisabete. As interfaces do direito agrário e dos direitos humanos e a segurança alimentar. São Paulo: Cultura Acadêmica, 2009, p. 126.

${ }^{15}$ MANIGLIA, Elisabete. As interfaces do direito agrário e dos direitos humanos e a segurança alimentar. São Paulo: Cultura Acadêmica, 2009, p. 126.
} 
O despertar da década de 1990 assistiu à inclusão, no conceito de segurança alimentar, de questões afetas à qualidade nutricional, biológica, sanitária e nutricional dos alimentos. Outras questões, como equidade, justiça e ética, além da sustentabilidade, passam a influir na estruturação do conceito securitário.

No Brasil, os Planos de Desenvolvimento da década de 1970 orientaram o país para a produção agrícola baseada na monocultura de exportação e com uso de insumos tecnológicos, de forma a permitir o lucro fácil em detrimento dos interesses da sociedade brasileira. As lutas sociais que frutificaram a partir dessa opção de desenvolvimento nacional pressionaram os governantes da época quanto à fome e à miséria e o termo "segurança alimentar" é citado pela primeira vez, em 1985, em documento do Ministério da Agricultura intitulado "Segurança Alimentar: proposta de uma política de combate à fome”.

A tendência de crescimento da mobilização da sociedade impulsionou, inclusive, a criação de um Conselho Nacional da Segurança Alimentar no país, medida que almejava atender as necessidades alimentares da população e atingir a autossuficiência nacional na produção de alimentos e que impulsionou a realização, em 1986, da primeira Conferência Nacional de Alimentação e Nutrição ${ }^{16}$.

Nesse cenário, houve a inclusão do combate à fome entre as bandeiras do Movimento pela Ética na Política (MEP) - participante dos movimentos sociais que, junto com iniciativas civis, viriam a impulsionar o impeachment do ex-presidente Fernando Collor de Mello. Do MEP surgiria a Ação pela Cidadania, contra a Fome, a Miséria e pela Vida, idealizada pelo sociólogo Herbert de Souza (o "Betinho") e que conduziria as ações assistenciais da sociedade civil a um avanço na luta contra a fome ${ }^{17}$. A assunção de Itamar Franco, vice-presidente, ao poder traz consigo uma nova mentalidade. Ele declarou que o combate à fome seria uma prioridade absoluta em seu mandato ${ }^{18}$. Iniciativas desse governo, como a criação do Conselho Nacional de Segurança Alimentar (CONSEA), contribuíram fundamentalmente para a implementação de uma política nacional de segurança alimentar, assim como o mapa da fome elaborado pelo Instituto de Pesquisa Econômica Aplicada (IPEA) ${ }^{19}$.

\footnotetext{
${ }^{16}$ MANIGLIA, Elisabete. As interfaces do direito agrário e dos direitos humanos e a segurança alimentar. São Paulo: Cultura Acadêmica, 2009, p. 158.

${ }^{17}$ MALUF, Renato Sérgio Jamil. Segurança alimentar e nutricional. Petrópolis: Vozes, 2007, p. 82.

${ }^{18}$ WOLFF, Ana Carolina. Direito à soberania alimentar e ao patrimônio cultural: perspectivas para uma alimentação identitária. 2015. 135f. Dissertação (Mestrado em Direito) - Faculdade de Ciências Humanas e Sociais, Universidade Estadual Paulista “Júlio de Mesquita Filho", Franca, 2015, p. 27.

${ }^{19}$ MANIGLIA, Elisabete. As interfaces do direito agrário e dos direitos humanos e a segurança alimentar. São Paulo: Cultura Acadêmica, 2009, p. 149; 159.
} 
Dois importantes avanços podem ser relacionados à criação do CONSEA, de acordo com Flávio Valente:

1. O combate à fome e à miséria passa a ser visto como um problema de Governo (sic) e uma questão estratégica, sua coordenação ficando diretamente vinculada ao gabinete do presidente; e

2. O objetivo de coordenar as ações governamentais de forma intersetorial, entre os diferentes níveis de governo, e com as da sociedade civil no sentido de reduzir duplicidades, superposições e de atingir os objetivos propostos ${ }^{20}$.

A partir de tais diretrizes e metas, evidencia-se que o CONSEA foi o grande responsável pela inserção efetiva, na ordem do dia da política brasileira, do tema da segurança alimentar.

Mesmo com as conquistas obtidas, no governo Fernando Henrique Cardoso o CONSEA é extinto e substituído pelo Conselho da Comunidade Solidária, que não manteve o foco na questão alimentar e elaborou estratégias de desenvolvimento social que ficaram no campo meramente teórico.

A extinção do referido conselho teve por base ideológica a própria ideia de Estado idealizada no governo de Fernando Henrique Cardoso e o seu embate com as concepções sociais vigentes no CONSEA. O governo tinha como meta estabilizar a economia brasileira e, para isso, tomava medidas que inserissem o país como mais um player na economia global; já o conselho partia de um patamar mínimo de dignidade social, com vistas a enfrentar a precariedade das condições de vida da maior parcela da população brasileira - o que foi utilizado como justificativa para o seu fechamento ${ }^{21}$.

A retomada efetiva da luta contra a fome e pela segurança alimentar na agenda política brasileira ocorreu no governo de Luís Inácio Lula da Silva, com a criação do Programa Fome Zero e a recriação do CONSEA. Com a continuidade dos eventos e debates sobre o tema, construiu-se um conceito de conceito de segurança alimentar brasileiro que veio a ser promulgado em 2006, pela Lei Orgânica de Segurança Alimentar e Nutricional (LOSAN), em seu artigo $3^{\circ}$, a saber:

A segurança alimentar e nutricional consiste na realização do direito de todos ao acesso regular e permanente a alimentos de qualidade, em quantidade suficiente, sem comprometer o acesso a outras necessidades essenciais, tendo como base práticas alimentares promotoras de saúde que respeitem a

20 VALENTE, Flávio Luiz Schieck. O direito à alimentação. In: LIMA JÚNIOR, Jayme Benvenuto; ZETTERSTROM, Lena (Orgs.). Extrema pobreza no Brasil: a situação do direito à alimentação e moradia adequada. Rio Grande do Sul: Loyola, 2002, p. 51-108.

21 VALENTE, Flávio Luiz Schieck. O direito à alimentação. In: LIMA JÚNIOR, Jayme Benvenuto; ZETTERSTROM, Lena (Orgs.). Extrema pobreza no Brasil: a situação do direito à alimentação e moradia adequada. Rio Grande do Sul: Loyola, 2002, p. 51-108. 
SEGURANCCA ALIMENTAR VS. GLOBALIZAÇÃO ECONÔMICA: POSSIVEIS AMEACCAS À SUSTENTABILIDADE AMBIENTAL, À BIODIVERSIDADE E AOS DIREITOS HUMANOS AGROALIMENTARES

diversidade cultural e que sejam ambiental, cultural, econômica e socialmente sustentáveis ${ }^{22}$.

O conceito legal brasileiro sobre o tema foi estruturado tendo por base o desenvolvimento histórico dos direitos humanos e sociais. Não é mais possível existir dúvida quanto ao fato de que alimentação adequada é um direito fundamental do homem e, mais do que isso, é inerente à dignidade da pessoa humana. A relevância do direito à alimentação é tamanha que o próprio legislador o entende como sendo indispensável à realização dos direitos constitucionais pátrios ${ }^{23}$.

Uma vez assegurada a posição de destaque da alimentação adequada no ordenamento jurídico brasileiro, as medidas para efetivar sua existência seriam cruciais. Para isso, determinou-se que o Poder Público deveria adotar as políticas e ações fundamentais para a promoção e garantia da segurança alimentar e nutricional da população em caráter permanente, independentemente das alterações político-governamentais no país ${ }^{24}$.

A partir da promulgação da lei, a segurança alimentar e nutricional converteu-se em objetivo público, estratégico e permanente, características que a colocaram entre as categorias nucleares para a formulação das políticas de desenvolvimento de um país ${ }^{25}$.

De acordo com o art. $4^{\circ}$ da LOSAN, a abrangência da segurança alimentar e nutricional inclui:

I - a ampliação das condições de acesso aos alimentos por meio da produção, em especial da agricultura tradicional e familiar, do processamento, da industrialização, da comercialização, incluindo-se os acordos internacionais, do abastecimento e da distribuição dos alimentos, incluindo-se a água, bem como da geração de emprego e da redistribuição da renda;

II - a conservação da biodiversidade e a utilização sustentável dos recursos;

III - a promoção da saúde, da nutrição e da alimentação da população, incluindose grupos populacionais específicos e populações em situação de vulnerabilidade social;

IV - a garantia da qualidade biológica, sanitária, nutricional e tecnológica dos alimentos, bem como seu aproveitamento, estimulando práticas alimentares e

\footnotetext{
22 BRASIL. Lei n. 11.346, de 15 set. 2006. Cria o Sistema Nacional de Segurança Alimentar e Nutricional SISAN com vistas em assegurar o direito humano à alimentação adequada e dá outras providências. Diário Oficial da União, Brasília, DF, 18 set. 2006.

${ }^{23}$ BRASIL. Lei n. 11.346, de 15 set. 2006. Cria o Sistema Nacional de Segurança Alimentar e Nutricional SISAN com vistas em assegurar o direito humano à alimentação adequada e dá outras providências. Diário Oficial da União, Brasília, DF, 18 set. 2006.

${ }^{24}$ WOLFF, Ana Carolina. Direito à soberania alimentar e ao patrimônio cultural: perspectivas para uma alimentação identitária. 2015. 135f. Dissertação (Mestrado em Direito) - Faculdade de Ciências Humanas e Sociais, Universidade Estadual Paulista "Júlio de Mesquita Filho", Franca, 2015, p. 30.

${ }^{25}$ MALUF, Renato Sérgio Jamil. Segurança alimentar e nutricional. Petrópolis: Vozes, 2007.
} 
estilos de vida saudáveis que respeitem a diversidade étnica e racial e cultural da população;

$\checkmark$ - a produção de conhecimento e o acesso à informação; e

VI - a implementação de políticas públicas e estratégias sustentáveis e participativas de produção, comercialização e consumo de alimentos, respeitando-se as múltiplas características culturais do País ${ }^{26}$.

O texto da lei brasileira sobre segurança alimentar chegou, inclusive, a ser apresentado como modelo de legislação sobre o tema aos demais Estados-partes do Mercosul, destacando-se posteriormente a importância da promoção conjunta de programas de seguridade alimentar e nutricional voltados às populações dos países ligados ao referido bloco econômico ${ }^{27}$.

\section{PANORAMA ATUAL DA AGRICULTURA E GLOBALIZAÇÃO ECONÔMICA}

Inserida no contexto da globalização econômica, a atual agricultura passa por um processo de modernização a partir dos anos 1960, com a implementação da chamada "Revolução Verde". Esse conjunto de corolários fez surgirem novos objetivos para a produção agrícola, a serem alcançados através de novas formas de produção vegetal e animal. Entendia-se necessária tal adesão, à época, para que a humanidade não perecesse em razão da falta de alimentos no pós-guerra.

Além disso, o avanço agrícola trouxe consigo a ideia de desenvolvimento. A expansão das fronteiras agrícolas no Brasil, sob os novos mandamentos do setor, permitiu que os grandes latifundiários e empresários do setor obtivessem cada vez mais lucros com a comercialização de gêneros agropecuários. 0 grande problema é que tal orientação levou a péssimas consequências econômicas e sociais para a população mais diretamente dependente do meio rural, como a engessada estrutura fundiária no Brasil e o uso de trabalho análogo ao de escravo, além de problemas ambientais, suportados de forma desigual pela sociedade.

No tocante às implicações ambientais, verifica-se que os trabalhadores agrícolas, seus familiares e dependentes, bem como os demais grupos étnicos que vivem e dependem umbilicalmente do campo (e que são desprovidos de poder real) sofrem de forma desproporcional os riscos ambientais que são induzidos socialmente. No caso da produção

\footnotetext{
${ }^{26}$ BRASIL. Lei n. 11.346, de 15 set. 2006. Cria o Sistema Nacional de Segurança Alimentar e Nutricional SISAN com vistas em assegurar o direito humano à alimentação adequada e dá outras providências. Diário Oficial da União, Brasília, DF, 18 set. 2006.

${ }^{27}$ GRASSI NETO, Roberto. Segurança alimentar: da produção agrária à proteção do consumidor. São Paulo: Saraiva, 2013, p. 117-118.
} 
SEGURANCCA ALIMENTAR VS. GLOBALIZAÇÃO ECONÔMICA: POSSIVEIS AMEACAS À SUSTENTABILIDADE AMBIENTAL, À BIODIVERSIDADE E AOS DIREITOS HUMANOS AGROALIMENTARES

ELISABETE MANIGLIA GIL RAMOS DE CARVALHO NETO

agrícola, pode-se falar especialmente da modificação e extração dos recursos naturais existentes, além da permanência de resíduos de insumos (por exemplo, de agrotóxicos) no ambiente.

Esse cenário surge em razão da adoção de um modelo neoliberal que veio a ser preponderante em todo o Ocidente, especialmente a partir do final da década de 1970 e início da década de 1980. Tal modelo prega a maior ampliação possível do setor da produção de mercadorias e, simultaneamente, a menor intervenção possível por parte do Estado, vista como empecilho para o desenvolvimento econômico ${ }^{28}$.

Tais políticas econômicas são contrárias aos interesses da maioria da população e afetam o Brasil como um todo, até mesmo no campo alimentar. Nesse sentido, Renato Maluf diz:

O atual modelo de gestão da economia e das contas públicas atende prioritariamente aos setores do grande capital que lhe dão sustentação e limita as possibilidades de tratar dos fatores que condicionam o acesso aos alimentos e a sua produção em bases equitativas e sustentáveis. Fica também inibida a introdução de instrumentos inovadores de política pública. Entre seus efeitos estão o pífio crescimento da produção e das oportunidades de trabalho, a lenta redução da desigualdade de renda, o apoio ao modelo agroexportador concentrador e danoso ao meio ambiente e a timidez da reforma agrária; ao mesmo tempo em que persiste a drenagem de vultosos recursos para a especulação financeira nacional e internacional sob a forma do pagamento das dívidas internas e externas ${ }^{29}$.

As relações de produção, assim, colocaram a agricultura a um momento novo em sua história: a concentração e controle do capital estrangeiro por meio de grupos ou setores produtivos, dispersando a produção pelos vários cantos do planeta. Isso leva a economia, a sociedade e a política a se transformarem, com notória influência nos direitos humanos.

Esse cenário evidencia a transição da sociedade moderna para a sociedade de risco de Ulrich Beck, na qual as instituições passam a ser produtoras e legitimadoras das ameaças e não possuem plenas condições de mantê-las sob controle ${ }^{30}$. Nessa nova configuração de sociedade, a distribuição dos riscos não corresponde às diferenças sociais, econômicas e geográficas da

\footnotetext{
${ }^{28}$ SANTOS, Janaína Silva dos. Problemáticas da segurança alimentar e nutricional no Brasil e o papel da pequena propriedade rural na efetivação de políticas públicas contra a fome e na proteção do meio ambiente. 2012. 102f. Trabalho de Conclusão de Curso (Bacharel em Direito) - Faculdade de Ciências Humanas e Sociais, Universidade Estadual Paulista “Julio de Mesquita Filho", Franca, 2012, p. 68.

${ }^{29}$ MALUF, Renato Sérgio Jamil. Segurança alimentar e nutricional. Petrópolis: Vozes, 2007, p. 125.

${ }^{30}$ BECK, Ulrich. A reinvenção da política: rumo a uma teoria da modernização reflexiva. In: BECK, Ulrich; GIDDENS, Anthony; LASH, Scott. Modernização reflexiva: política, tradição e estética na ordem social moderna. São Paulo: Editora da Universidade Estadual Paulista, 1997, p. 15.
} 
modernidade clássica, o que traz o paradoxo do alto desenvolvimento científico-tecnológico em contraponto às consequências imprevisíveis para a saúde humana e para o meio ambiente ${ }^{31}$.

De acordo com a teoria de Ulrich Beck, a sociedade de risco teria duas fases: a primeira se trata de um momento em que os efeitos e as autoameaças são elaborados de forma constante, mas não chegam a se tornar questões públicas ou o centro de conflitos políticos, já que as ameaças produzidas através de tomadas de decisão são consideradas como "riscos residuais"32; já a segunda fase se evidencia quando os perigos da sociedade industrial passam a dominar os debates e conflitos públicos, tanto políticos quanto privados ${ }^{33}$.

Ulrich Beck considerou como principais riscos os ecológicos, químicos, nucleares e genéticos, que são "produzidos industrialmente, externalizados economicamente, individualizados juridicamente, legitimados cientificamente e minimizados politicamente" ${ }^{34}$. Ainda segundo ele, a incerteza científica - aliada à incompletude do conhecimento na área pode levar a duas formas de riscos ecológicos possíveis, a saber: “(a) risco concreto ou potencial (visível e previsível pelo conhecimento); (b) risco abstrato (invisível e imprevisível pelo conhecimento humano)"35.

Esses riscos, assim, estariam, inicialmente, ao alcance do poder - mas o resultado das influências recíprocas entre o poder e a economia, a sociedade e a política, no mundo atual, acaba sendo imprevisível. Até mesmo o poder tem sua parcela de indefinição: para Michel Foucault, as relações de poder não estão apenas afetas ao nível do direito e nem da violência; dessa forma, não são basicamente contratuais e nem apenas repressivas ${ }^{36}$. José Esteve Pardo,

\footnotetext{
${ }^{31}$ GUIVANT, Julia Silvia. A teoria da sociedade de risco de Ulrich Beck: entre o diagnóstico e a profecia. Estudos Sociedade e Agricultura, n. 16, abril 2001, p. 95-112. Disponível em: http://bibliotecavirtual.clacso.org.ar/ar/libros/brasil/cpda/estudos/dezesseis/julia16.htm. Acesso em: 08 mar. 2019.

${ }^{32}$ BECK, Ulrich. A reinvenção da política: rumo a uma teoria da modernização reflexiva. In: BECK, Ulrich; GIDDENS, Anthony; LASH, Scott. Modernização reflexiva: política, tradição e estética na ordem social moderna. São Paulo: Editora da Universidade Estadual Paulista, 1997, p. 15.

${ }^{33}$ BECK, Ulrich. A reinvenção da política: rumo a uma teoria da modernização reflexiva. In: BECK, Ulrich; GIDDENS, Anthony; LASH, Scott. Modernização reflexiva: política, tradição e estética na ordem social moderna. São Paulo: Editora da Universidade Estadual Paulista, 1997, p. 15.

${ }^{34}$ GUIVANT, Julia Silvia. A teoria da sociedade de risco de Ulrich Beck: entre o diagnóstico e a profecia. Estudos Sociedade e Agricultura, n. 16, abril 2001, p. 95-112. Disponível em: http://bibliotecavirtual.clacso.org.ar/ar/libros/brasil/cpda/estudos/dezesseis/julia16.htm. Acesso em 08 mar. 2019.

${ }_{35}$ LEITE, José Rubens Morato; AYALA, Patryck de Araújo.Transdisciplinariedade e a proteção jurídicoambiental em sociedades de risco: direito, ciência e participação. In: LEITE, José Rubens Morato; BELLO FILHO, Ney de Barros (org.). Direito Ambiental Contemporâneo. Barueri: Manole, 2004. p. 102.

${ }^{36}$ FOUCAULT, Michel. Microfísica do poder. 27. ed. Rio de Janeiro: Edições Graal, 2009, p. XV.
} 
inclusive, afirma que o Direito sempre se adaptou rapidamente de forma a receber os avanços da tecnociência e assegurar o seu sucesso ${ }^{37}$.

Eugène Enriquez, por sua vez, lembra que as instituições existem somente pela vontade operatória que possuem e, assim, buscarão dominar tudo o que possa ser dominado, valendo-se dos mecanismos do psiquismo ${ }^{38}$. Logo, a arena de disputa político-jurídica pelo poder pode se valer do "desconhecimento" proposto por Enriquez - no sentido de 'conhecimento equivocado' sobre a política - para continuar perpetuando a estruturação do poder e, assim, o cenário vigente da agricultura e, possivelmente de formas diferenciadas em razão das peculiaridades sociais de cada país, também da globalização econômica.

\section{SUSTENTABILIDADE AMBIENTAL E PROTEÇÃO À BIODIVERSIDADE}

A definição de agricultura é que se trata de "conjunto de trabalhos que objetivam transformar o solo para a cultura de vegetais" 39 . Evidencia-se, assim, que o mero trabalho de cultivo feito pelo homem/ser humano pode ocasionar degradação ambiental se não houver preocupação com a sustentabilidade.

A preocupação com a sustentabilidade e a crise ambiental não é atual. A Conferência sobre o Meio Ambiente em Estocolmo (Suécia), no ano de 1972, que reconheceu a crise ambiental global vivida pela humanidade, foi a primeira grande iniciativa mundial promovida pela ONU para debater tais questões - embora ainda com enfoque maior no ser humano. Dessa conferência resultou uma importante declaração, denominada Convenção de Estocolmo de 1972, que explicitou a necessidade de atenção às questões ambientais:

Princípio 18 - A ciência e a tecnologia, como parte de sua contribuição ao desenvolvimento econômico e social, devem ser aplicadas para evitar, identificar e controlar os riscos que ameaçam o meio ambiente e para solucionar os problemas ambientais, em benefício do bem comum da humanidade ${ }^{40}$.

Posteriormente, a continuidade dos estudos e debates levou ao surgimento de documentos como o relatório "Limites do Crescimento" no ano de 1972, feito pelo Clube de

\footnotetext{
${ }^{37}$ PARDO, José Esteve. Técnica, riesgo y derecho. Barcelona: Ariel S.A., 1999.

38 ENRIQUEZ, Eugène. Instituições, poder e "desconhecimento". In: ARAÚJO, José Newton Garcia de; CARRETEIRO, Teresa Cristina (Orgs.). Cenários sociais e abordagem clínica. São Paulo: Escuta; Belo Horizonte: Fumec, 2001, p. 68.

39 GRANDE ENCICLOPÉDIA LAROUSSE CULTURAL. São Paulo: Ed. Universo, 1990, v. 1, p. 65.

40 BRASIL. Ministério do Meio Ambiente. Declaração da Conferência das Nações Unidas para o Meio Ambiente Humano. Disponível em:
} http://www.mma.gov.br/estruturas/agenda21/_arquivos/estocolmo.doc. Acesso em 27 ago. 2016. 
Roma, que denunciou a inviabilidade da manutenção dos níveis de exploração natural e industrialização da época, pois a Terra suportaria apenas mais 100 anos naquele cenário.

Dessa forma, um novo paradigma de desenvolvimento sustentável se fez necessário. Em 1973 surgiu o termo ecodesenvolvimento, proposto por Maurice Strong e apresentado como alternativa da concepção clássica de desenvolvimento, cuja articulação inicial foi feita por Ignacy Sachs ${ }^{41}$. Essa conceituação viria a dar origem ao termo desenvolvimento sustentável, ligado à ideia de sustentabilidade.

Em continuidade, a Comissão Mundial da ONU sobre o Meio Ambiente e Desenvolvimento (UNCED) elaborou um documento chamado "Nosso Futuro Comum", que conceituou “desenvolvimento sustentável" como "atender às necessidades do presente, sem comprometer a possibilidade de as gerações futuras atenderem a suas próprias necessidades" ${ }^{42}$.

Percebe-se então que a humanidade incorporou aspectos de sustentabilidade para orientar o desenvolvimento futuro especialmente com o surgir dos estudos e documentos apontados, mas a ideia de sustentabilidade tem suas raízes na história do ser humano. 0 desejo de viver em harmonia com a natureza faz parte de nossa herança evolutiva ${ }^{43}$.

Para que haja desenvolvimento sustentável, é fundamental perceber a essência ecológica do conceito: ou existe desenvolvimento sustentável ecológico ou não existe desenvolvimento sustentável algum ${ }^{44}$. A sustentabilidade tem como característica principal a possível e desejável conciliação entre o desenvolvimento integral, a preservação do meio ambiente e a melhoria da qualidade de vida, sendo que as três metas são indispensáveis ${ }^{45}$.

Quanto à produção de alimentos na sociedade pós-industrial atual, devem ser considerados os aspectos relativos às relações de produção agrícola e a sustentabilidade. A opção por cultivos geneticamente modificados acaba por se inserir em um modelo agrícola de produção convencional voltada para o agronegócio, com o uso de agrotóxicos e fertilizantes, o que não é adequado no aspecto ecológico. A agroecologia, por sua vez, é considerada como uma ciência que busca tratar de questões não tratadas pela ciência clássica - dentre elas, a

\footnotetext{
${ }^{41}$ BELLEN, Hans Michael van. Indicadores de sustentabilidade: uma análise comparativa. 2. ed. Rio de Janeiro: Editora FGV, 2006, p. 21-22.

${ }^{42}$ COMISSÃO MUNDIAL SOBRE MEIO AMBIENTE E DESENVOLVIMENTO. Nosso Futuro Comum. 2. ed. Rio de Janeiro: Editora FGV, 1991, p. 46.

${ }^{43}$ BOSSELMANN, Klaus. 0 princípio da sustentabilidade: transformando direito e governança. Tradução de Phillip Gil França. São Paulo: Editora Revista dos Tribunais, 2015, p. 29.

${ }^{44}$ BOSSELMANN, Klaus. O princípio da sustentabilidade: transformando direito e governança. Tradução de Phillip Gil França. São Paulo: Editora Revista dos Tribunais, 2015, p. 42.

${ }^{45}$ MILARÉ, Édis. Direito do ambiente: a gestão ambiental em foco - doutrina, jurisprudência, glossário. 6. ed. rev., atual. e ampl. São Paulo: Editora Revista dos Tribunais, 2009, p. 64.
} 
ISSN 1981-3694

(DOI): $10.5902 / 1981369437953$

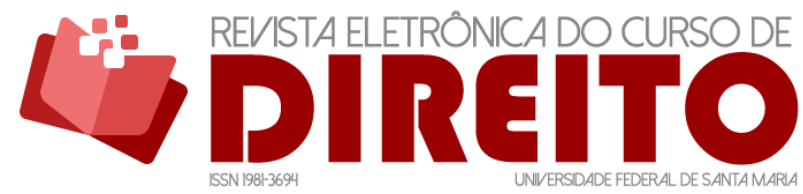

SEGURANÇA ALIMENTAR VS. GLOBALIZAÇÃO ECONÔMICA:

POSSÍVEIS AMEAÇAS À SUSTENTABILIDADE AMBIENTAL, À BIODIVERSIDADE E AOS DIREITOS HUMANOS AGROALIMENTARES

ELISABETE MANIGLIA GIL RAMOS DE CARVALHO NETO

sustentabilidade - e pode ser uma alternativa ao modelo de produção agrícola baseado em transgênicos. Um ponto importante, porém, é o de que a ciência ainda não solucionou a questão sobre as alternativas acerca do atual modelo de produção ${ }^{46}$.

Além das relações de produção, pode-se relacionar a questão às organizações que dela participam. No tocante à sustentabilidade as empresas têm se incorporado ao debate ecológico nas últimas décadas, mas somente em caso de incremento dos lucros haverá mudanças. Assim, tendo em vista que há outros importantes interesses em pauta - e não somente o econômico - o debate deve estar aberto a todos os interessados ${ }^{47}$.

No tocante à biodiversidade e sua preservação, a agricultura está relacionada de várias formas. Em relação ao pacote tecnológico da Revolução Verde, pode-se mencionar as questões afetas ao uso de agrotóxicos - que poluem o solo, os cursos d'água e exterminam diversas formas de vida, podendo prejudicar todas as espécies vivas. Quando a sua pulverização é realizada pela via aérea, o potencial de prejuízo à diversidade biológica pode se tornar ainda maior. Danos aos solos pelo uso de fertilizantes químicos também são legados que o atual modelo de produção pode deixar para a natureza.

Nem mesmo a técnica mais recente está livre de negatividades. 0 uso de organismos geneticamente modificados (OGM) na agricultura pode causar diversos danos às espécies, a partir do deslocamento de genes, formação de plantas daninhas e insetos resistentes, além dos riscos para a alimentação. Dessa maneira, os princípios da prevenção e da precaução devem ser observados quanto aos riscos da atividade produtiva.

Caso a atividade agrícola acabe por optar pela utilização dos cultivos geneticamente modificados, a produção deve se compatibilizar com a proteção ambiental. Para isso, a fiel submissão às normas jurídicas brasileiras e ao ideal de máxima proteção ambiental previsto no artigo 225 da Constituição Federal de 1988 é imprescindível. Deve ocorrer uma análise prévia dos impactos ambientais que o empreendimento econômico pode causar à natureza, com a adoção de medidas compensatórias e mitigadoras do prejuízo ambiental - preferencialmente com a obtenção dos benefícios econômicos da atividade sem que haja danos ambientais, em respeito ao princípio jurídico da prevenção.

Dentro dessa ótica ambiental, também é fundamental que exista total certeza científica de que a atividade não violará o equilíbrio ambiental - mesmo que seja necessário tomar alguma medida prévia para obter tal garantia, conforme ditames do princípio jurídico da precaução.

\footnotetext{
${ }^{46}$ LACEY, Hugh. Há alternativas ao uso dos transgênicos? Novos Estudos, n. 78, julho 2007, p. 31-39.

${ }^{47}$ FOLADORI, Guillermo. Limites do desenvolvimento sustentável. Campinas: Editora da Unicamp, 2001.
} 
Como há riscos em todas as atividades humanas, torna-se importante verificar se o benefício a ser obtido através da atividade econômica em estudo é proporcional ao impacto negativo que a mesma poderia causar ao meio ambiente ${ }^{48}$.

Paulo Affonso Leme Machado explicita que a aplicação do princípio da prevenção desdobra-se em pelo menos doze itens:

1) Identificação e inventário das espécies animais e vegetais de um território, quanto à conservação da natureza;

2) Identificação das fontes contaminantes da água e do ar, quanto ao controle da poluição;

3) Identificação e inventário dos ecossistemas, com a elaboração de um mapa ecológico;

4) Planejamento ambiental e econômico integrados;

5) Ordenamento territorial ambiental para a valorização das áreas de acordo com a sua aptidão;

6) Estudo de Impacto Ambiental;

7) Prestação de informações contínuas e completas;

8) Emprego de novas tecnologias;

9) Autorização ou licenciamento ambiental;

10) Monitoramento;

11) Inspeção e auditoria ambientais; e

12) Sanções administrativas ou judiciais ${ }^{49}$.

A partir desse rol, evidencia-se que a doutrina traz opções ao Poder Público para que esta possa atender ao princípio da prevenção. No âmbito normativo, a própria PNMA traz, em seu artigo $9^{\circ}$, instrumentos que têm por objetivo dar efetividade à norma. Dentre eles, João Carlos de Carvalho Rocha afirma que, em relação à discussão de prevenção de dano decorrente de atividade econômica afeta à biotecnologia, destacam-se dois deles: o zoneamento ambiental (inciso II) e a avaliação de impactos ambientais (inciso III) ${ }^{50}$.

O zoneamento ambiental (ou ecológico-econômico) foi regulamentado pelo Decreto $\mathrm{n}^{\circ}$ 4.297/2002, que estabelece os critérios para tal medida geográfica, de forma a assegurar a qualidade ambiental ${ }^{51}$. Uma vez que no Brasil ocorre o plantio simultâneo de lavouras tradicionais, de tipo orgânico e com uso de plantas geneticamente modificadas - cada um com

${ }^{48} \mathrm{KISS}$, Alexandre. Os direitos e interesses das gerações futuras e o princípio da precaução. In: VARELLA, Marcelo Dias; PLATIAU, Ana Flávia Barros (Org.). Princípio da precaução. Belo Horizonte: Del Rey, 2004, p. 11.

${ }^{49}$ MACHADO, Paulo Affonso Leme. Direito Ambiental Brasileiro. 19. ed., rev., atual. e ampl. São Paulo: Malheiros Editores, 2011, p. 99.

${ }^{50}$ ROCHA, João Carlos de Carvalho. Direito Ambiental e transgênicos: princípios fundamentais da biossegurança. Belo Horizonte: Del Rey, 2008, p. 177-178.

${ }^{51}$ BRASIL. Decreto $n^{\circ} 4.297$, de 10 de julho de 2002. Regulamenta o art. 9o, inciso II, da Lei no 6.938, de 31 de agosto de 1981, estabelecendo critérios para o Zoneamento Ecológico-Econômico do Brasil - ZEE, e dá outras providências. Diário Oficial da República Federativa do Brasil, Brasília, DF, 11 jul. 2002. Disponível em: http://www.planalto.gov.br/ccivil_03/decreto/2002/D4297.htm. Acesso em 10 mar. 2019. 
um regramento específico - e que há a necessidade de proteção também das espécies silvestres, pois são estas que vão manter a biodiversidade futura, a realização do zoneamento será imperativa para que não ocorra contaminação envolvendo as diversas formas de vida no entorno e além dele.

Inclusive, a Convenção sobre Diversidade Biológica (CDB) positiva, em seu artigo $8^{\circ}$, alínea e, que as partes contratantes da norma devem "promover o desenvolvimento sustentável e ambientalmente sadio em áreas adjacentes às áreas protegidas a fim de reforçar a proteção dessas áreas" ${ }^{52}$. O Brasil se sujeita a tal regra, já que promulgou a Convenção em março de 1998 e a mesma já vigorava no país desde 29 de maio de 1994.

Por sua vez, a avaliação de impacto ambiental, prevista na PNMA, é procedimento reconhecido internacionalmente e também consta da CDB, em seu artigo $14^{53}$. Assim, para averiguação preliminar sobre as consequências da existência do empreendimento agrário que utilize OGM, o Poder Público é obrigado a exigir o Estudo de Impacto Ambiental (EIA), conforme disposição constitucional inserta no artigo 225, inciso IV: "exigir, na forma da lei, para instalação de obra ou atividade potencialmente causadora de significativa degradação do meio ambiente, estudo prévio de impacto ambiental, a que se dará publicidade" ${ }^{54}$.

Uma observação a ser feita é que a Lei de Biossegurança (Lei no 11.105/2005), em seu artigo $16, \S 3^{\circ}$, determina que a Comissão Técnica Nacional de Biossegurança (CTNBio) seria detentora da prerrogativa de deliberar, de forma definitiva e derradeira, sobre a necessidade do licenciamento ambiental ${ }^{55}$. Entende-se que essa determinação deve ser lida em conformidade com a Constituição Federal, pois ainda não há certeza científica sobre a segurança dos

\footnotetext{
${ }^{52}$ BRASIL. Decreto $\mathrm{n}^{\circ} 2.519$, de 16 de março de 1998. Promulga a Convenção sobre Diversidade Biológica, assinada no Rio de Janeiro, em 05 de junho de 1992. Diário Oficial da República Federativa do Brasil, Brasília, DF, 17 mar. 1998. Disponível em: http://www.planalto.gov.br/ccivil_03/decreto/D2519.htm. Acesso em 10 mar. 2019.

53 ROCHA, João Carlos de Carvalho. Direito Ambiental e transgênicos: princípios fundamentais da biossegurança. Belo Horizonte: Del Rey, 2008, p. 178.

54 BRASIL. Constituição Federal. Brasília: Senado Federal, 1988. Disponível em: http://www.planalto.gov.br/ccivil_03/Constituicao/Constituicao.htm. Acesso em: 09 mar. 2019.

${ }_{55}$ BRASIL. Lei $n^{\circ} 11.105$, de 24 de março de 2005. Regulamenta os incisos II, IV e V do $\S 10$ do art. 225 da Constituição Federal, estabelece normas de segurança e mecanismos de fiscalização de atividades que envolvam organismos geneticamente modificados - OGM e seus derivados, cria o Conselho Nacional de Biossegurança - CNBS, reestrutura a Comissão Técnica Nacional de Biossegurança - CTNBio, dispõe sobre a Política Nacional de Biossegurança - PNB, revoga a Lei no 8.974, de 5 de janeiro de 1995, e a Medida Provisória no 2.191-9, de 23 de agosto de 2001, e os arts. 5o, 60, 7o, 8o, 9o, 10 e 16 da Lei no 10.814, de 15 de dezembro de 2003, e dá outras providências. In: Diário Oficial da República Federativa do Brasil, Brasília, DF, 28 mar. 2005. Disponível em: http://www.planalto.gov.br/ccivil_03/_Ato20042006/2005/Lei/L11105.htm. Acesso em 10 mar. 2019.
} 
organismos geneticamente modificados e, assim sendo, o EIA tem que ser obrigatoriamente realizado nesses casos - e não ficar à mercê daquela Comissão.

Após a realização do EIA e elaboração do decorrente Relatório de Impacto Ambiental (RIMA), que sintetiza o estudo em linguagem mais acessível ao amplo debate, caso a decisão técnico-política seja a de permissão do empreendimento - especialmente em razão de eventual necessidade alimentar existente - mesmo sabendo que não há certeza científica de segurança quanto aos derivados de OGM, torna-se necessário tomar medidas preservacionistas.

Os recursos genéticos originais das espécies vivas podem ser preservados através do uso de bancos ativos de germoplasma - unidades conservadoras de material genético de uso imediato ou com potencial de uso futuro, nas quais não ocorre o descarte de acessos - diferentemente das chamadas "coleções de trabalho", nas quais se elimina o que não interessa ao melhoramento genético ${ }^{56}$.

Embora o uso desse tipo de banco possa atenuar problemas afetos a genes, sua manutenção é bastante dispendiosa. Assim, o aspecto econômico pode influenciar tanto na opção produtiva adotada (OGM) como a alternativa para a defesa e manutenção da biodiversidade, com os países desenvolvidos causando o problema e fornecendo, eles mesmos, a solução, já que as grandes multinacionais do setor estão sediadas em seus territórios e as melhores condições de criação e manutenção de bancos de germoplasma também serão aquelas existentes no interior de suas fronteiras. Não se pode negar, todavia, que há um importante ponto positivo: a manutenção da variabilidade genética, fundamental para eventual reconstituição da biodiversidade.

O declínio de espécies da biodiversidade, de acordo com Miguel Guerra, Fernando Rocha e Rubens Nodari, tem cinco causas: "a destruição e fragmentação dos ecossistemas, a introdução de espécies exóticas invasoras, a sobre-exploração dos recursos genéticos, a poluição e as mudanças climáticas ou ainda diferentes combinações destas" ${ }^{27}$. Todas elas devem ser evitadas pelo modo de produção agrícola, sob pena de o próprio homem ser o grande prejudicado com suas consequências.

\footnotetext{
56 RODRIGUES, Walter Fagundes. Variabilidade genética de milho (Zea mays), feijão (Phaseolus vulgaris) e cucurbitáceas em unidades de produção agroecológica na região sul do Rio Grande do Sul. 2012. 63f. Dissertação (Mestrado em Sistemas de Produção Agrícola Familiar) - Faculdade de Agronomia Eliseu Maciel, Universidade Federal de Pelotas, Pelotas, 2012.

57 GUERRA, Miguel Pedro; ROCHA, Fernando Souza; NODARI, Rubens Onofre. Biodiversidade, recursos genéticos vegetais e segurança alimentar em um cenário de ameaças e mudanças. In: VEIGA, Renato Ferraz de Arruda; QUEIROZ, Manoel Abílio de (Eds.). Recursos fitogenéticos: a base da agricultura sustentável no Brasil. Viçosa-MG: Editora UFV, 2015, p. 42.
} 
Por sua própria natureza, sabe-se que a agricultura tem o dever de produzir - e essa produção precisa focar principalmente nos alimentos que abastecerão a humanidade. Porém, no cenário civilizatório e jurídico atual, as atividades econômicas não podem se alicerçar da forma que thes for mais adequada para a obtenção do lucro máximo. 0 avanço do conhecimento científico e a sua crescente divulgação permitem que a produção - neste caso, a agrícola - possa ocorrer através de princípios e práticas agroecológicas e sustentáveis. Essa opção traz consigo a possibilidade de aumento da diversidade de espécies que podem ser usadas para as finalidades agroalimentares e, ainda, contribui para minimizar as externalidades - efeitos colaterais a terceiros não envolvidos com a atividade - nos agroecossistemas ${ }^{58}$.

Dessa maneira, a opção pela agroecologia - considerando-se que esta é uma forma de produção que não utiliza agrotóxicos e que se vale da adubação natural - contribui de forma significativa para a sustentabilidade ambiental, já que pode otimizar a produção a partir do uso de insumos internos e, assim, manter a conservação de recursos ambientais no tempo. 0 incremento tecnológico aplicável à agroecologia, além de eventual incentivo à inovação nesse tipo de produção, pode ensejar na maior produção de alimentos, com elevada qualidade biológica e sem prejudicar a biodiversidade e os ecossistemas.

\section{CONCLUSÃO}

A humanidade construiu, em sua caminhada histórica, direitos humanos básicos inerentes a todo ser humano, sendo que os mesmos foram consagrados mundialmente após a Segunda Guerra Mundial, muito por causa dos horrores vivenciados e decorrentes do conflito armado. Alguns dos principais direitos fundamentais reconhecidos a partir de então são o direito humano à alimentação, à vida, à paz e ao meio ambiente.

Quando se pensa no direito humano à alimentação e sua evolução até os dias atuais, percebe-se que o instituto da segurança alimentar foi conceituado de forma a buscar garantir uma alimentação adequada e segura, levando em conta aspectos relativos às práticas alimentares que fossem, dentre outras características, sustentáveis ambientalmente. $\mathrm{Na}$ atualidade, isso se revela um problema.

\footnotetext{
${ }^{58}$ GUERRA, Miguel Pedro; ROCHA, Fernando Souza; NODARI, Rubens Onofre. Biodiversidade, recursos genéticos vegetais e segurança alimentar em um cenário de ameaças e mudanças. In: VEIGA, Renato Ferraz de Arruda; QUEIROZ, Manoel Abílio de (Eds.). Recursos fitogenéticos: a base da agricultura sustentável no Brasil. Viçosa-MG: Editora UFV, 2015, p. 39-52.
} 
O modelo produtivo majoritário na agricultura, que é a atividade humana fornecedora de alimentos por excelência, é o do agronegócio concebido sob um paradigma neoliberal. Os pilares da produção são o uso de agrotóxicos e fertilizantes propostos pela Revolução Verde, com a monocultura de exportação e a produção em latifúndios. Isso possibilitou a expansão das fronteiras agrícolas e grandes lucros para uma pequena parcela da população, mas os interesses econômicos e sociais daqueles que dependem do campo para sua subsistência foram solapados. Além disso, tais bases agrícolas apresentam diversos riscos para o homem/ser humano e para o meio ambiente e podem assim contribuir significativamente para a redução da biodiversidade. No cenário de globalização econômica vivido na atualidade, as alternativas a esse modelo hegemônico são escassas. Não há uma conciliação eficaz dos aspectos ecológico e econômico, de forma que a toda a humanidade possa se alimentar de forma adequada e segura.

Portanto, são necessários estudos e busca de alternativas para que se possa conquistar, no contexto da globalização econômica, opções verdadeiramente adequadas à segurança alimentar plena, que protejam a biodiversidade e, assim, respeitem na totalidade os direitos humanos relacionados.

\section{REFERÊNCIAS}

ARRIAGA, Rodrigo Neves. A política ambiental brasileira e gaúcha: evolução, aspectos legais e seus instrumentos. 2011. 55f. Monografia (Especialização em Economia e Meio Ambiente). Setor de Ciências Agrárias, Universidade Federal do Paraná, Curitiba, 2011.

BECK, Ulrich. A reinvenção da política: rumo a uma teoria da modernização reflexiva. In: BECK, Ulrich; GIDDENS, Anthony; LASH, Scott. Modernização reflexiva: política, tradição e estética na ordem social moderna. São Paulo: Editora da Universidade Estadual Paulista, 1997, p. 11-71.

BELLEN, Hans Michael van. Indicadores de sustentabilidade: uma análise comparativa. 2. ed. Rio de Janeiro: Editora FGV, 2006.

BISPO, Vanesca Freitas. Direito fundamental à alimentação adequada: a efetividade do direito pelo mínimo existencial e a reserva do possível. Curitiba: Juruá, 2014.

BOSSELMANN, Klaus. O princípio da sustentabilidade: transformando direito e governança. Tradução de Phillip Gil França. São Paulo: Editora Revista dos Tribunais, 2015.

BRASIL. Constituição Federal. Brasília: Senado Federal, 1988. Disponível em: http://www.planalto.gov.br/ccivil_03/Constituicao/Constituicao.htm . Acesso em: 09 mar. 2019. 
BRASIL. Constituição (1988). Emenda Constitucional $n^{\circ}$ 64, de 04 de fevereiro de 2010. Diário Oficial da República Federativa do Brasil, Brasília, DF, 04 fev. 2010. Disponível em:

http://www.planalto.gov.br/ccivil_03/Constituicao/Emendas/Emc/emc64.htm\#art1. Acesso em: 09 mar. 2019.

BRASIL. Decreto $n^{\circ} 2.519$, de 16 de março de 1998. Promulga a Convenção sobre Diversidade Biológica, assinada no Rio de Janeiro, em 05 de junho de 1992. Diário Oficial da República Federativa do Brasil, Brasília, DF, 17 mar. 1998. Disponível em:

http://www.planalto.gov.br/ccivil_03/decreto/D2519.htm . Acesso em 10 mar. 2019.

BRASIL. Decreto ${ }^{\circ} 4.297$, de 10 de julho de 2002. Regulamenta o art. 9o, inciso II, da Lei no 6.938, de 31 de agosto de 1981, estabelecendo critérios para o Zoneamento EcológicoEconômico do Brasil - ZEE, e dá outras providências. Diário Oficial da República Federativa do Brasil, Brasília, DF, 11 jul. 2002. Disponível em: http://www.planalto.gov.br/ccivil_03/decreto/2002/D4297.htm . Acesso em 10 mar. 2019.

BRASIL. Lei $n^{\circ} 6.938$, de 31 de agosto de 1981. Dispõe sobre a Política Nacional do Meio Ambiente, seus fins e mecanismos de formulação e aplicação, e dá outras providências. In: Diário Oficial da República Federativa do Brasil, Brasília, DF, 02 set. 1981. Disponível em: http://www.planalto.gov.br/ccivil_03/leis/L6938.htm . Acesso em 09 mar. 2019.

BRASIL. Lei $n^{\circ} 11.105$, de 24 de março de 2005. Regulamenta os incisos II, IV e V do $\S 10$ do art. 225 da Constituição Federal, estabelece normas de segurança e mecanismos de fiscalização de atividades que envolvam organismos geneticamente modificados - OGM e seus derivados, cria o Conselho Nacional de Biossegurança - CNBS, reestrutura a Comissão Técnica Nacional de Biossegurança - CTNBio, dispõe sobre a Política Nacional de Biossegurança - PNB, revoga a Lei no 8.974, de 5 de janeiro de 1995, e a Medida Provisória no 2.191-9, de 23 de agosto de 2001, e os arts. 5o, 6o, 7o, 8o, 9o, 10 e 16 da Lei no 10.814, de 15 de dezembro de 2003, e dá outras providências. In: Diário Oficial da República Federativa do Brasil, Brasília, DF, 28 mar. 2005. Disponível em: http://www.planalto.gov.br/ccivil_03/_Ato2004-2006/2005/Lei/L11105.htm. Acesso em 10 mar. 2019.

BRASIL. Lei n. 11.346, de 15 de setembro de 2006. Cria o Sistema Nacional de Segurança Alimentar e Nutricional - SISAN com vistas em assegurar o direito humano à alimentação adequada e dá outras providências. Diário Oficial da União, Brasília, DF, 18 set. 2006. Disponível em: http://www.planalto.gov.br/ccivil_03/_ato2004-2006/2006/lei/l11346.htm. Acesso em: 27 ago. 2016.

BRASIL. Ministério do Meio Ambiente. Declaração da Conferência das Nações Unidas para o Meio Ambiente Humano. Disponível em: http://www.mma.gov.br/estruturas/agenda21/_arquivos/estocolmo.doc. Acesso em 27 ago. 2016.

COMISSÃO MUNDIAL SOBRE MEIO AMBIENTE E DESENVOLVIMENTO. Nosso Futuro Comum. 2. ed. Rio de Janeiro: Editora FGV, 1991. Disponível em: https://edisciplinas.usp.br/pluginfile.php/4245128/mod_resource/content/3/Nosso\%20Futuro\%2 0Comum.pdf. Acesso em 16 fev. 2019. 
ENRIQUEZ, Eugène. Instituições, poder e “desconhecimento”. In: ARAÚJO, José Newton Garcia de; CARRETEIRO, Teresa Cristina (Orgs.). Cenários sociais e abordagem clínica. São Paulo: Escuta; Belo Horizonte: Fumec, 2001, p. 49-74.

ESTORNINHO, Maria João. Segurança alimentar e protecção do consumidor de organismos geneticamente modificados. Coimbra: Edições Almedina, 2008.

FOLADORI, Guillermo. Limites do desenvolvimento sustentável. Campinas: Editora da Unicamp, 2001.

FOUCAULT, Michel. Microfísica do poder. 27. ed. reimpr. Rio de Janeiro: Edições Graal, 2009.

GRANDE ENCICLOPÉDIA LAROUSSE CULTURAL. São Paulo. Ed. Universo, 1990, v.1.

GRASSI NETO, Roberto. Segurança alimentar: da produção agrária à proteção do consumidor. São Paulo: Saraiva, 2013.

GUERRA, Miguel Pedro; ROCHA, Fernando Souza; NODARI, Rubens Onofre. Biodiversidade, recursos genéticos vegetais e segurança alimentar em um cenário de ameaças e mudanças. In: VEIGA, Renato Ferraz de Arruda; QUEIROZ, Manoel Abílio de (Eds.). Recursos fitogenéticos: a base da agricultura sustentável no Brasil. Viçosa-MG: Editora UFV, 2015, p. 39-52.

GUIVANT, Julia Silvia. A teoria da sociedade de risco de Ulrich Beck: entre o diagnóstico e a profecia. Estudos Sociedade e Agricultura, n. 16, abril 2001, p. 95-112. Disponível em: http://bibliotecavirtual.clacso.org.ar/ar/libros/brasil/cpda/estudos/dezesseis/julia16.htm . Acesso em 08 mar. 2019.

KISS, Alexandre. Os direitos e interesses das gerações futuras e o princípio da precaução. In: VARELLA, Marcelo Dias; PLATIAU, Ana Flávia Barros (Org.). Princípio da precaução. Belo Horizonte: Del Rey, 2004.

LACEY, Hugh. Há alternativas ao uso dos transgênicos? Novos Estudos. n. 78, julho 2007, p.3139.

LEITE, José Rubens Morato; AYALA, Patryck de Araújo.Transdisciplinariedade e a proteção jurídico-ambiental em sociedades de risco: direito, ciência e participação. In: LEITE, José Rubens Morato; BELLO FILHO, Ney de Barros (Org.). Direito Ambiental Contemporâneo. Barueri: Manole, 2004. p. 99-126.

MACHADO, Paulo Affonso Leme. Direito Ambiental Brasileiro. 19. ed., rev., atual. e ampl. São Paulo: Malheiros Editores, 2011.

MALUF, Renato Sérgio Jamil. Segurança alimentar e nutricional. Petrópolis: Vozes, 2007.

MANIGLIA, Elisabete. As interfaces do direito agrário e dos direitos humanos e a segurança alimentar. São Paulo: Cultura Acadêmica, 2009.

MILARÉ, Édis. Direito do ambiente: a gestão ambiental em foco - doutrina, jurisprudência, glossário. 6. ed. São Paulo: Editora Revista dos Tribunais, 2009. 
PARDO, José Esteve. Técnica, riesgo y derecho. Barcelona: Ariel S.A., 1999.

ROCHA, João Carlos de Carvalho. Direito Ambiental e transgênicos: princípios fundamentais da biossegurança. Belo Horizonte: Del Rey, 2008.

RODRIGUES, Walter Fagundes. Variabilidade genética de milho (Zea mays), feijão (Phaseolus vulgaris) e cucurbitáceas em unidades de produção agroecológica na região sul do Rio Grande do Sul. 2012. 63f. Dissertação (Mestrado em Sistemas de Produção Agrícola Familiar) Faculdade de Agronomia Eliseu Maciel, Universidade Federal de Pelotas, Pelotas, 2012.

SANTOS, Janaína Silva dos. Problemáticas da segurança alimentar e nutricional no Brasil e o papel da pequena propriedade rural na efetivação de políticas públicas contra a fome e na proteção do meio ambiente. 2012. 102f. Trabalho de Conclusão de Curso (Bacharel em Direito) - Faculdade de Ciências Humanas e Sociais, Universidade Estadual Paulista "Julio de Mesquita Filho", Franca, 2012.

SIQUEIRA, Dirceu Pereira. Teoria geral do direito à alimentação: cultura, cidadania e legitimação. Birigui: Boreal Editora, 2015.

VALENTE, Flávio Luiz Schieck. Do combate à fome à segurança alimentar e nutricional: o direito à alimentação adequada. In: VALENTE, Flávio Luiz Schieck (Org.). Direito humano à alimentação: desafios e conquistas. São Paulo: Cortez, 2002.

VALENTE, Flávio Luiz Schieck. O direito à alimentação. In: LIMA JÚNIOR, Jayme Benvenuto; ZETTERSTROM, Lena (Orgs.). Extrema pobreza no Brasil: a situação do direito à alimentação e moradia adequada. Rio Grande do Sul: Loyola, 2002. p. 51-108.

WOLFF, Ana Carolina. Direito à soberania alimentar e ao patrimônio cultural: perspectivas para uma alimentação identitária. 2015. 135f. Dissertação (Mestrado em Direito) - Faculdade de Ciências Humanas e Sociais, Universidade Estadual Paulista "Júlio de Mesquita Filho", Franca, 2015.

Recebido em: 02.05.2019 / Revisões requeridas em: 09.04.2020 / Aprovado em: 05.06.2020 / Publicado em: 08.07.2020

\section{COMO FAZER REFERÊNCIA AO ARTIGO (ABNT):}

MANIGLIA, Elisabete; CARVALHO NETO, Gil Ramos de. Segurança alimentar vs. globalização econômica: possíveis ameaças à sustentabilidade ambiental, à biodiversidade e aos direitos humanos agroalimentares. Revista Eletrônica do Curso de Direito da UFSM, Santa Maria, RS, v. 15, n. 2, e37953, maio./ago. 2020. ISSN 1981-3694. DOI: http://dx.doi.org/10.5902/1981369437953. Disponível em: https://periodicos.ufsm.br/revistadireito/article/view/37953. Acesso em: dia mês. ano.

Direitos autorais 2020 Revista Eletrônica do Curso de Direito da UFSM

Editores responsáveis: Rafael Santos de Oliveira e Angela Araujo da Silveira Espindola

Esta obra está licenciada com uma Licença Creative Commons Atribuição-NãoComercial-SemDerivações 4.0 Internacional. 
ISSN 1981-3694

(DOI): $10.5902 / 1981369437953$

SEGURANÇA ALIMENTAR VS. GLOBALIZAÇÃO ECONÔMICA: POSSIVEIS AMEACAS À SUSTENTABILIDADE AMBIENTAL, À BIODIVERSIDADE E AOS DIREITOS HUMANOS AGROALIMENTARES

\section{SOBRE O/A AUTOR/A}

\section{ELISABETE MANIGLIA}

Possui graduação em Comunicação Social Jornalismo pela Universidade de São Paulo (1975), graduação em Direito pela Universidade Estadual Paulista Júlio de Mesquita Filho (1988), mestrado em Direito pela Universidade de São Paulo (1994) e doutorado em Direito pela Universidade Estadual Paulista Júlio de Mesquita Filho (2000).Defendeu livre docência em 2007 e atualmente é professora adjunto da Universidade Estadual Paulista Júlio de Mesquita Filho. Tem experiência na área de Direito, com ênfase em Direito Agrário e ambiental rural, atuando principalmente nos seguintes temas: reforma agrária, direito agrário, trabalho rural, direito empresarial rural e direitos humanos.Sua área de pesquisa esta voltada neste momento para produção agraria , segurança alimentar e políticas públicas de sustentabilidade rural. Membro da Comissão de Direito Agrário, da Rede Nacional de Advogados Populares (RENAP), Ordem dos Advogados do Brasil, Associação Brasileira de Reforma Agrária (ABRA), Associação Brasileira de Direito Agrário (ABDA).

\section{GiL Ramos de Carvalho Neto}

Bacharel em Direito pela Universidade Estadual Paulista Júlio de Mesquita Filho - UNESP, mestre em Ciência, Tecnologia e Sociedade pela UFSCar - Universidade Federal de São Carlos, especialista em Direito Ambiental pela UFPR - Universidade Federal do Paraná. Mestre em Direito pela Universidade Estadual Paulista Júlio de Mesquita Filho - UNESP, campus de Franca/SP. Foi docente do curso de Administração (2013-2017) da UNIESP S/A, campus de Ibitinga-SP. Tem experiência com as áreas de Direito Ambiental, Direito Agrário e Propriedade Intelectual. 